\title{
Research on Driving Factors of Implicit Human Capital for Elite Retired Athlete Based on Grounded Theory
}

\author{
Yu-Bin Liu \\ Scientific Research Office, \\ Tianjin University of Finance and Economics, \\ Tianjin, China \\ E-mail: lionel817@163.com
}

\begin{abstract}
The implicit human capital of elite retired athletes plays an important role in the process of retirement transformation and re-employment, which has an important influence on the sustainable development of our competitive sports industry. For this reason, this paper employs two researching methods of materialization which are case study and grounded theory and picks two representative elite retired athletes' successful transition, including Deng Yaping and Huang Yanlan. The key driving factors in the process of elite retired athletes' implicit human capital are self-perception, role transition, athletic characteristic, motivation, and social capital, opportunity, learning ability, innovation and competency.
\end{abstract}

Keywords-elite retired athlete; implicit human capital's transformation; driving factors; grounded theory

\section{INTRODUCTION}

Under the environment of market economy, the problems in the aftercare of the retired athletes show the transitional feature from the implementation of the state's relative settlement policy to choose their own jobs and economic compensation. It means that the human capital of athletes as the competitive core capital involved in the market economy. "1] "Zou Chunlan phenomenon" reflects the difficult employment situation of some retired athletes, attracting great attention in China. Liu Yubin and Zhang Shan (2013) on the basis of defining the concept and characteristics of implicit human capital, analyzed the mechanism of the transformation of elite athletes' implicit human capital, proposed that the main reason why most athletes are in trouble after retiring is that they do not make full play of the role of the implicit human capital when retired transformation and role transition. Under the environment of market economy, if retired athletes want to fully realize personal value should identify and exploit their own implicit human capital, improve the driving factors in the process of retired athletes' implicit human capital, form employment competitiveness. In this way we can provide new platforms for retired athletes' career planning and provide new idea for competitive sports to develop in a healthy way in China.

This paper picks two representative elite retired athletes' successful transition, including Deng Yaping and Huang Yanlan, using grounded theory and extracting the key driving factors in the process of elite retired athletes' implicit human capital, then through further cross case comparison and analysis, summing up the common driving forces of the

\author{
Shan Zhang, Shao-Qing Geng \\ Management Department, \\ Tianjin University of Finance and Economics, \\ Tianjin, China \\ E-mail: gsq7777@126.com
}

two cases and the inner link between the driving forces, providing theoretical support for retired athletes' career management.

\section{STUDY DESIGN}

\section{A. Method}

For athletes' implicit human capital changing process research is still in the early exploration stage, existing research has yet to explain the concept and transformation mechanism of athletes' implicit human capital, theory construction is the blank of this area. It is difficult to conclude the driving factors and transformation mechanism of retired athletes' implicit human capital and to explain dynamic evolution of driving factors by theoretical model or empirical analysis. ${ }^{[2]}$ Qualitative research is rooted in reality, through the continuous interaction between researchers and research objects, insight into the nature of the object of the study, to summarize, refine the concept and theoretical framework from the phenomenon. The grounded theory proposed by Glasser and Strauss is identified as scientific methodology of "found theory from the information". ${ }^{[5]}$ This method inductive and refine the concept and category through three steps include the open coding, axial coding and selective coding. Then to reveal the relationship between the concept and category, to link every category through the story finally form the grounded theory.

\section{B. Sample Selection}

This study divided sporting events into two types, including highly commercialized sports (such as basketball, tennis, volleyball, football, table tennis, badminton, golf and so on) and low grade commercial sports (such as weightlifting, shoot, gymnastics, rowing, dive and so on), based on the commercial value, the focus on it, the number of participants and business spending of the sport. Dividing the retired transformation of the athletes into four types based on two dimension (commercial degree of the sporting events and the smooth degree of the retired transformation), as shown in Figure 1. This study refers to the different types of retired transformation and selects the case in the first quadrant (Deng Yaping) and the second quadrant (Huang Yanlan) as the research object of grounded theory. 


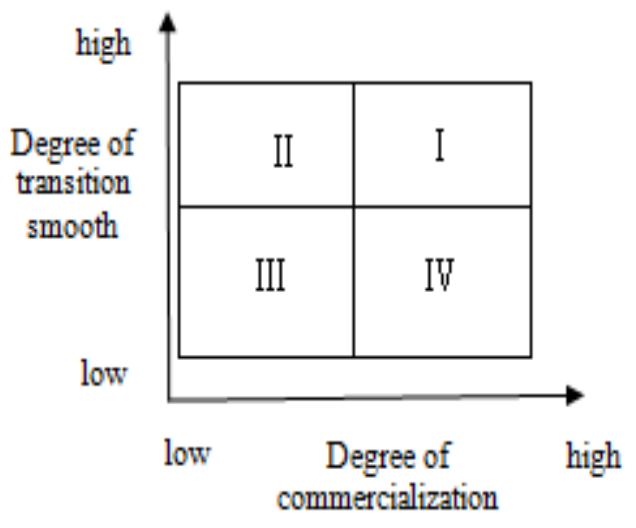

Figure 1. retired athlete transformation types

\section{GROUNDED ANALYSIS}

In this paper, taking grounded study finish the above three steps of the two cases, and then carrying out cross case study, that is, through the comparative analysis of the various categories and core areas, the driving factors that affect the transformation of the implicit human capital of elite retired athletes are summarized.

\section{A. Open Coding}

Through the open mind of the original material of verbatim decomposition, will form the concept of classification, comparison and recombination, summed up and extracted a category. According to the Getz (2008) study, at the beginning of this stage, the decoding is wide, then gradually reduced, until the code number saturation. ${ }^{[9]}$ Deng Yaping retired transformation case materials open coding, after finishing decomposition obtained 66 tag (a1a66), extract 51 concepts (aa1- aa51), set up a corresponding with the 51 level of the subject ( A1-A51). According to the logical connections between the concepts, dividing the 51 subject headings into three types (correlativity, synonymy, belongingness) based on the semantic relation among these subject headings. Through the classification of the concept of category, refining out of the 37 categories (AA1-AA37), the specific open coding process is too complex, not in this paper.

TABLE I. THE EXAMPLE OF THE TOPIC WORDS SEMANTIC RELATIONS IN THE CASE OF DENG YAPING

\begin{tabular}{|c|c|c|c|}
\hline & correlativity & synonymy & Belongingness \\
\hline $\begin{array}{l}\text { Relationship } \\
\text { meaning }\end{array}$ & $\begin{array}{l}\text { There is a certain correlation between different } \\
\text { subject words, mainly reflected in the path, the } \\
\text { process and the results of the correlation. }\end{array}$ & $\begin{array}{c}\text { The expression form of subject words is } \\
\text { not the same, but it is the same } \\
\text { phenomenon or event. }\end{array}$ & $\begin{array}{l}\text { In the scope of the subject terms, the } \\
\text { relation is that of including and included. }\end{array}$ \\
\hline $\begin{array}{l}\text { One-level } \\
\text { ect headings }\end{array}$ & $\begin{array}{c}\mathrm{A}_{1} \mathrm{~A}_{2} \mathrm{~A}_{3} \mathrm{~A}_{6}, \mathrm{~A}_{7} \mathrm{~A}_{15} \mathrm{~A}_{16} \\
\mathrm{~A}_{5} \mathrm{~A}_{17} \mathrm{~A}_{18} \mathrm{~A}_{35}, \mathrm{~A}_{34} \mathrm{~A}_{36} \\
\mathrm{~A}_{8} \mathrm{~A}_{9} \mathrm{~A}_{10} \mathrm{~A}_{11}, \mathrm{~A}_{50} \mathrm{~A}_{51} \mathrm{~A}_{52} \\
\mathrm{~A}_{42} \mathrm{~A}_{47} \mathrm{~A}_{53}, \mathrm{~A}_{43} \mathrm{~A}_{48} \mathrm{~A}_{49} \\
\mathrm{~A}_{44} \mathrm{~A}_{46} \mathrm{~A}_{58} \mathrm{~A}_{59}\end{array}$ & $\begin{array}{c}\mathrm{A}_{19} \mathrm{~A}_{20} \mathrm{~A}_{22}, \mathrm{~A}_{4} \mathrm{~A}_{23}, \\
\mathrm{~A}_{30} \mathrm{~A}_{32}, \mathrm{~A}_{31} \mathrm{~A}_{33}, \\
\mathrm{~A}_{39} \mathrm{~A}_{41}, \mathrm{~A}_{40} \mathrm{~A}_{55} \mathrm{~A}_{56}\end{array}$ & $\begin{array}{c}\mathrm{A}_{13}-\mathrm{A}_{12} \mathrm{~A}_{1}, \mathrm{~A}_{27}-\mathrm{A}_{28} \mathrm{~A}_{29} \\
\mathrm{~A}_{26}-\mathrm{A}_{24} \mathrm{~A}_{25}, \mathrm{~A}_{37}-\mathrm{A}_{38} \\
\mathrm{~A}_{54}-\mathrm{A}_{21} \mathrm{~A}_{57}\end{array}$ \\
\hline Sample & $\begin{array}{l}\text { A7(Study hard) } \\
\text { A15(devote themselves fully to their study) } \\
\text { A16(Active learning) } \\
\text { The study of Deng Yaping's learning attitude } \\
\text { in the course of study is described from three } \\
\text { different perspectives. }\end{array}$ & $\begin{array}{l}\text { A31(self -analysis) } \\
\text { A33 (capacity analysis), } \\
\text { The expression of the meaning is that } \\
\text { Deng Yaping analyzes the capacity of } \\
\text { herself before retirement. }\end{array}$ & $\begin{array}{l}\text { A27(higher visibility and influence) } \\
\text { Include the A28 (personal popularity) and } \\
\text { A29 (apparent identity). }\end{array}$ \\
\hline
\end{tabular}

According to the same research method, after analyzing the raw materials of Huang Yanlan's retired transformation , 61 label (a1-a61 said, 56 concept (aa1-aa56) and 56 level subject headings, shown in A1-A56.The relationship among these 56 subject headings are correlativity, synonymy, belongingness too, as shown in Table 2. A total of 41 categories (with AA1-AA41), the specific open coding process is more complex, not in this paper. 
TABLE II. THE EXAMPLE OF THE TOPIC WORDS SEMANTIC RELATIONS IN THE CASE OF HUANG YANLAN

\begin{tabular}{|c|c|c|c|}
\hline & correlativity & synonymy & belongingness \\
\hline $\begin{array}{l}\text { Relationship } \\
\text { meaning }\end{array}$ & $\begin{array}{l}\text { There is a certain correlation between different } \\
\text { subject words, mainly reflected in the path, the } \\
\text { process and the results of the correlation. }\end{array}$ & $\begin{array}{l}\text { The expression form of subject words } \\
\text { is not the same, but it is the same } \\
\text { phenomenon or event. }\end{array}$ & $\begin{array}{l}\text { In the scope of the subject terms, the } \\
\text { relation is that of including and included. }\end{array}$ \\
\hline $\begin{array}{l}\text { One-level } \\
\text { subject } \\
\text { headings }\end{array}$ & $\begin{array}{c}\mathrm{A}_{4} \mathrm{~A}_{5} \mathrm{~A}_{39}, \mathrm{~A}_{8} \mathrm{~A}_{9} \mathrm{~A}_{21} \mathrm{~A}_{42} \\
\mathrm{~A}_{6} \mathrm{~A}_{34}, \mathrm{~A}_{12} \mathrm{~A}_{13} \mathrm{~A}_{44}, \mathrm{~A}_{22} \mathrm{~A}_{23} \\
\mathrm{~A}_{15} \mathrm{~A}_{16} \mathrm{~A}_{17} \mathrm{~A}_{20} \mathrm{~A}_{24} \\
\mathrm{~A}_{30} \mathrm{~A}_{36} \mathrm{~A}_{45}, \mathrm{~A}_{46} \mathrm{~A}_{47} \\
\mathrm{~A}_{48} \mathrm{~A}_{49}, \mathrm{~A}_{51} \mathrm{~A}_{55}, \mathrm{~A}_{52} \mathrm{~A}_{53} \mathrm{~A}_{54}\end{array}$ & $\begin{array}{c}\mathrm{A}_{3} \mathrm{~A}_{29}, \mathrm{~A}_{7} \mathrm{~A}_{26} \mathrm{~A}_{27} \\
\mathrm{~A}_{10} \mathrm{~A}_{18} \mathrm{~A}_{28}, \mathrm{~A}_{25} \mathrm{~A}_{41} \\
\mathrm{~A}_{43}-\mathrm{A}_{40}\end{array}$ & $\begin{array}{c}\mathrm{A}_{32}-\mathrm{A}_{1} \mathrm{~A}_{14} \mathrm{~A}_{38}, \mathrm{~A}_{33^{-}} \mathrm{A}_{37} \\
\mathrm{~A}_{56^{-}}-\mathrm{A}_{35}, \mathrm{~A}_{2} \mathrm{~A}_{19} \mathrm{~A}_{50}\end{array}$ \\
\hline Sample & $\begin{array}{l}\mathrm{A}_{12} \text { (initial business difficulties) } \\
\mathrm{A}_{13} \text { (loss of business) } \\
\mathrm{A}_{44} \text { (high procurement costs) } \\
\text { These described the Huang Yanlan's initial } \\
\text { business difficulties) }\end{array}$ & $\begin{array}{l}\mathrm{A}_{7}(\text { family help) } \\
\mathrm{A}_{26} \text { (Friends of the help) } \\
\mathrm{A}_{27} \text { (family support), } \\
\text { These explained the help and support } \\
\text { derived from family and friends in } \\
\text { Huang Yanlan's business process) }\end{array}$ & $\begin{array}{l}\mathrm{A}_{2} \text { (entrepreneurial success) contains the } \\
\mathrm{A}_{19} \text { (business upturn) and } \mathrm{A}_{50} \text { (open three } \\
\text { stores). }\end{array}$ \\
\hline
\end{tabular}

(Date source: compiled by author)

\section{B. Axial Coding}

From the paradigm model of Table 3, this study found that the process of Deng YaPing's retired transformation and role transition mainly includes three main categories: continuing education, self-cognition and social capital. The first major category formed by active learning attitude, dare to challenge the danger, character and the help from Juan Antonio Samaranch and $\mathrm{Wu}$ Shaozu that motivate her diligent efforts to learn and successfully complete her studies, this is the main support that driven Deng Yaping shift from the athlete to student. Second main categories contain the optimistic in the face of retirement, planning retirement career before retiring, self-analysis and Samaranch's recommendations. Self-cognitive activity, not only in the coordination of individual physiological and psychological activities, but also can quickly adapt to the social role and the impact of the surrounding environment. Third main categories include the celebrity effect, a wide range of human resources; play a personal advantage and so on. According to the structural hole theory of Ronald Bert (1992), when the individual in a social network in the center of the structure hole, it will have more resources and information, the more social capital. ${ }^{[14]}$ Deng Yaping with rich experience and a wide range of network resources get rid of the limitation of working in the field of sports, successfully finish the large span transformation from sports to the politics.

TABLE III. THE MAIN CATEGORY AND PARADIGM MODEL OF DENG YAPING'S RETIRED TRANSFORMATION

\begin{tabular}{|c|c|c|c|}
\hline \multirow{2}{*}{ Project } & \multicolumn{3}{|c|}{ Main category } \\
\hline & continuing education & self-perception & social capital \\
\hline $\begin{array}{l}\text { Causal } \\
\text { conditions }\end{array}$ & $\begin{array}{l}\text { Lack of knowledge }\left(\mathrm{AA}_{1}\right) \\
\text { Look forward to going to school }\left(\mathrm{AA}_{18}\right) \\
\text { Work need }\left(\mathrm{AA}_{3}\right)\end{array}$ & Face retired transformation $\left(\mathrm{AA}_{28}\right)$ & Internet newcomer $\left(\mathrm{AA}_{42}\right)$ \\
\hline $\begin{array}{l}\text { The nature of } \\
\text { causal } \\
\text { conditions }\end{array}$ & $\begin{array}{l}\text { Poor communication in English }\left(\mathrm{AA}_{2}\right) \\
\text { Weak English foundation }\left(\mathrm{AA}_{6}\right) \\
\text { In service learning English condition is } \\
\text { limited }\left(\mathrm{AA}_{13}\right)\end{array}$ & $\begin{array}{l}\text { Start from zero }\left(\mathrm{AA}_{32}\right) \\
\text { Lack of } \\
\text { competitiveness }\left(\mathrm{AA}_{30}\right)\end{array}$ & $\begin{array}{l}\text { Initial stage }\left(\mathrm{AA}_{43}\right) \\
\text { Rich working experience }\left(\mathrm{AA}_{34}\right)\end{array}$ \\
\hline phenomenon & $\begin{array}{l}\text { Initial stage }\left(\mathrm{AA}_{43}\right) \\
\text { Rich working experience }\left(\mathrm{AA}_{34}\right)\end{array}$ & Self -perception $\left(\mathrm{AA}_{27}\right)$ & social capital $\left(\mathrm{AA}_{46}\right)$ \\
\hline
\end{tabular}


TABLE III. THE MAIN CATEGORY AND PARADIGM MODEL OF DENG YAPING'S RETIRED TRANSFORMATION (CONTINUED)

\begin{tabular}{|c|c|c|c|}
\hline action context & Active learning $\left(\mathrm{AA}_{13}\right)$ & Optimistic facing retirement $\left(\mathrm{AA}_{26}\right)$ & Celebrity effect $\left(\mathrm{AA}_{36}\right)$ \\
\hline $\begin{array}{l}\text { Intermediary } \\
\text { conditions }\end{array}$ & $\begin{array}{l}\text { the personality of the courage to } \\
\text { challenge, to meet the difficult } \\
\text { personality }\left(\mathrm{AA}_{8}\right) \\
\text { the personality of indomitable and } \\
\text { feisty }\left(\mathrm{AA}_{10}\right) \\
\text { Samaranch's encouragement }\left(\mathrm{AA}_{17}\right) \\
\text { Wu Shaozu's help }\left(\mathrm{AA}_{18}\right)\end{array}$ & $\begin{array}{l}\text { Samaranch's advice }\left(\mathrm{AA}_{16}\right)(\text { Good } \\
\text { psychological quality }\left(\mathrm{AA}_{52}\right)\end{array}$ & $\begin{array}{l}\text { Work passion and confidence }\left(\mathrm{AA}_{39}\right) \\
\text { Extensive network of resources }\left(\mathrm{AA}_{46}\right) \\
\text { Higher degree of concern }\left(\mathrm{AA}_{45}\right)\end{array}$ \\
\hline $\begin{array}{l}\text { Action / } \\
\text { interaction } \\
\text { strategy }\end{array}$ & $\begin{array}{l}\text { Hard working }\left(\mathrm{AA}_{7}\right) \\
\text { Devote herself fully to study }\left(\mathrm{AA}_{12}\right) \\
\text { Go abroad to study English }\left(\mathrm{AA}_{5}\right)\end{array}$ & $\begin{array}{l}\text { Prepare before retirting }\left(\mathrm{AA}_{24}\right) \\
\text { Planning ahead }\left(\mathrm{AA}_{25}\right) \\
\text { Self -analysis }\left(\mathrm{AA}_{29}\right)\end{array}$ & $\begin{array}{l}\text { Learn with an open mind }\left(\mathrm{AA}_{35}\right) \\
\text { team building }\left(\mathrm{AA}_{37}\right) \\
\text { Exert personal advantage }\left(\mathrm{AA}_{41}\right) \\
\text { Initiative to expand contacts }\left(\mathrm{AA}_{47}\right)\end{array}$ \\
\hline Result & $\begin{array}{l}\text { English rapid promotion }\left(\mathrm{AA}_{22}\right) \\
\text { Completed bachelor, master and doctoral } \\
\text { degrees in } 11 \text { years }\left(\mathrm{AA}_{21}\right)\end{array}$ & Decided to read $\left(\mathrm{AA}_{31}\right)$ & $\begin{array}{l}\text { Competent for new job }\left(\mathrm{AA}_{48}\right) \\
\text { Large span transformation }\left(\mathrm{AA}_{40}\right)\end{array}$ \\
\hline
\end{tabular}

From the paradigm model of Huang Yanlan's retirement in Table 4, summing up three main categories: repositioning the role, the continuation of the athletic spirit, innovative ideas. Facing the difficult retirement employment environment, Huang Yanlan with a positive and optimistic attitude, repositioning her roles and rely on her own efforts to start their own business. Perseverance, hard-working, and the athletic spirit of the courage to fight play the key role in the Huang Yanlan's venture so that she can quickly adapt to the surrounding environment, and constantly explore the business experience, to develop new markets. The spirit of innovation has been well interpreted in Huang Yanlan's entrepreneurial process. Product differentiation, quality and service are the basis for the opening of the branch.

TABLE IV. THE MAIN CATEGORY AND PARADIGM MODEL OF HUANGYANLAN'S RETIRED TRANSFORMATION

\begin{tabular}{|c|c|c|c|}
\hline \multirow[b]{2}{*}{ Project } & \multicolumn{3}{|c|}{ Main category } \\
\hline & Role relocation & Continuation of the spirit of the athletes & Innovation idea \\
\hline $\begin{array}{l}\text { Causal } \\
\text { conditions }\end{array}$ & Retirement employment difficulties $\left(\mathrm{AA}_{7}\right)$ & Initial business difficulties $\left(\mathrm{AA}_{11}\right)$ & Operating pressure $\left(\mathrm{AA}_{15}\right)$ \\
\hline $\begin{array}{l}\text { The nature of } \\
\text { causal } \\
\text { conditions }\end{array}$ & $\begin{array}{c}\text { Lack of work skills }\left(\mathrm{AA}_{8}\right) \\
\text { Lack of awareness of retirement }\left(\mathrm{AA}_{17}\right) \\
\text { Do not have advancing plan }\left(\mathrm{AA}_{29}\right)\end{array}$ & $\begin{array}{c}\text { High purchasing } \operatorname{cost}\left(\mathrm{AA}_{30}\right) \\
\text { Lack of entrepreneurial experience }\left(\mathrm{AA}_{28}\right)\end{array}$ & $\begin{array}{l}\text { Business is bleak }\left(\mathrm{AA}_{37}\right) \\
\text { Low familiarity }\left(\mathrm{AA}_{38}\right)\end{array}$ \\
\hline phenomenon & $\begin{array}{c}\text { Entrepreneurial orientation }\left(\mathrm{AA}_{4}\right) \\
\text { Positive and optimistic attitude }\left(\mathrm{AA}_{24}\right)\end{array}$ & $\begin{array}{c}\text { Endure hardships and be capable of hard } \\
\text { work }\left(\mathrm{AA}_{36}\right)\end{array}$ & Difference $\left(\mathrm{AA}_{5}\right)$ \\
\hline $\begin{array}{l}\text { action } \\
\text { context }\end{array}$ & Entrepreneurial sense $\left(\mathrm{AA}_{3}\right)$ & Positive psychological adaptation $\left(\mathrm{AA}_{35}\right)$ & Diversified marketing $\left(\mathrm{AA}_{14}\right)$ \\
\hline $\begin{array}{l}\text { Intermediary } \\
\text { conditions }\end{array}$ & $\begin{array}{l}\text { Self-perception }\left(\mathrm{AA}_{10}\right) \\
\text { friendsourcing }\left(\mathrm{AA}_{6}\right)\end{array}$ & $\begin{array}{c}\text { Achievement needs }\left(\mathrm{AA}_{26}\right) \text { Large market } \\
\text { demand }\left(\mathrm{AA}_{33}\right) \\
\text { Integrity management }\left(\mathrm{AA}_{16}\right) \\
\end{array}$ & $\begin{array}{c}\text { Price advantage }\left(\mathrm{AA}_{13}\right) \\
\text { Strong learning ability }\left(\mathrm{AA}_{20}\right)\end{array}$ \\
\hline $\begin{array}{l}\text { Action / } \\
\text { interaction } \\
\text { strategy }\end{array}$ & $\begin{array}{c}\text { Seize the opportunity to start a } \\
\text { business }\left(\mathrm{AA}_{32}\right) \\
\text { market research }\left(\mathrm{AA}_{27}\right)\end{array}$ & $\begin{array}{c}\text { Establish business objectives }\left(\mathrm{AA}_{21}\right) \\
\text { Exploration experience }\left(\mathrm{AA}_{41}\right) \\
\text { Open up the market }\left(\mathrm{AA}_{31}\right) \\
\end{array}$ & $\begin{array}{l}\text { Master customer resources }\left(\mathrm{AA}_{18}\right) \\
\text { Focus on quality and service }\left(\mathrm{AA}_{19}\right)\end{array}$ \\
\hline Result & Self-employed $\left(\mathrm{AA}_{2}\right)$ & Win customer credit $\left(\mathrm{AA}_{12}\right)$ & Entrepreneurial success $\left(\mathrm{AA}_{1}\right)$ \\
\hline
\end{tabular}

\section{Selective Coding}

According to the results of open coding and axial coding, along the guidance of main categories, this paper constructs Deng Yaping and Huang Yanlan's retired transformation story line respectively, on the basis of refines the core category of the two cases.

Deng Yaping retired transformation story line: lack of knowledge and weak English foundation---go abroad to study--- work at the International Olympic Committee--Samaranch (social network) --- Deputy Secretary of the
Beijing Municipal Communist Youth league---go to business in The People's Daily search engine. In the new field of Internet, Deng Yaping with its celebrity effect, give full play to her own advantages to actively expand contacts resources, propaganda and promotion the development of the company. Achieving the cross industry triple jump from students, officials to chief executive officer.

Huang Yanlan retired transformation story line: retired early due to injury---there is no early career planning for retirement, lack of practical skills and cultural qualities needed to work---self-employed. With players indomitable, 
hard-working spirit, Huang Yanlan explored entrepreneurship management experience, and constantly open up the new market and customer resources through the difference of marketing strategy, rely on own efforts to achieve the transformation of professional role.

\section{Core Category}

Based on the analysis of the driving factors, continuing education and self-perception play active roles in the transformation of Deng Yaping's retirement and the transformation of implicit human capital. Social capital is the key force in the evolution of the core category, can well explain the above story line. Therefore, this paper takes the social capital as the core category of the case study of the transformation of Deng Yaping's implicit human capital. In analyzing and sorting out of Huang Yanlan professional role transformation process, the researchers found that unyielding, perseverance, self-improvement etc. play a key role in the process of her own businesses and can well interpret the whole story line. Therefore, this article will continue the spirit of the athletes as the core category of Huang Yanlan's case.

\section{CORRELATION OF DRIVING FACTORS}

In order to further study the common factors and inner logic relationship among the factors of the implicit human capital of elite retired athletes' transformation, this study uses the cross case comparison to analyze the main category and core category and then refine the general point, dig the essence of the phenomenon. After open coding of the above two cases ,classification of the 92 categories (51 Deng Yaping case, Huang Yanlan case 41), extract 9 key points, using GG1-GG9 to represent the category of open decoding across case studies. These are the key points in the analysis of the original material, summarized on the basis of the summary of the regularity of the factors; it basically reflects the essence of the research object. A description of these 9 key points is compared, as shown in table 5.

TABLE V. COMPARISON OF KEY POINTS

\begin{tabular}{|c|c|c|c|}
\hline \multicolumn{2}{|r|}{ Key point } & Deng Yaping & Huang Yanlan \\
\hline $\begin{array}{l}\text { Role transition } \\
\mathrm{GG}_{1}\end{array}$ & $\begin{array}{c}\text { Psychological recovery } \\
\text { behavior }\end{array}$ & $\begin{array}{l}\text { Positive mental attitude } \\
\text { Start from zero }\end{array}$ & $\begin{array}{c}\text { Positive psychological adaptation } \\
\text { Repositioning }\end{array}$ \\
\hline Learn $\mathrm{GG}_{2}$ & Desire form & $\begin{array}{c}\text { Strong } \\
\text { Enter university }\end{array}$ & $\begin{array}{l}\text { Relatively strong } \\
\text { Self-learning }\end{array}$ \\
\hline $\begin{array}{l}\text { Social capital } \\
\mathrm{GG}_{3}\end{array}$ & Channel interactive quality & $\begin{array}{l}\text { Samaranch, Wu Shaozu, Internet industry } \\
\text { experts, etc. } \\
\text { Active development of network resources }\end{array}$ & $\begin{array}{l}\text { Family and friends } \\
\text { Actively expand the team }\end{array}$ \\
\hline $\begin{array}{l}\text { Self-perception } \\
\mathrm{GG}_{4}\end{array}$ & Shortcoming advantage & $\begin{array}{c}\text { Weak English foundation } \\
\text { Rich Experience, high visibility }\end{array}$ & $\begin{array}{c}\text { Lack of practical skills } \\
\text { Endure hardships and be capable of hard } \\
\text { work }\end{array}$ \\
\hline $\begin{array}{l}\text { athletic } \\
\text { characteristic } \\
\mathrm{GG}_{5}\end{array}$ & $\begin{array}{c}\text { Firm and indomitable } \\
\text { Hard working and enterprising } \\
\text { Seek to prevail over others team spirit }\end{array}$ & $\begin{array}{l}\text { Tenacious perseverance Dare to struggle } \\
\text { Indomitable spirit Focus on teamwork }\end{array}$ & $\begin{array}{c}\text { Unremittig self- improvement } \\
\text { Continuation of the spirit of hard work } \\
\text { Unyielding personality } \\
\text { Cooperation conscious-ness }\end{array}$ \\
\hline $\begin{array}{c}\text { Opportunity } \\
\text { GG }_{6}\end{array}$ & Susceptibility Recognition ability & $\begin{array}{c}\text { higher } \\
\text { Be good at grasping the opportunity }\end{array}$ & $\begin{array}{c}\text { high } \\
\text { Seize the opportunity }\end{array}$ \\
\hline Innovation $\mathrm{GG}_{7}$ & Consciousness performance & $\begin{array}{c}\text { Open stance } \\
\text { Constantly seeking innovation in the work }\end{array}$ & $\begin{array}{c}\text { dare to try } \\
\text { Adjust management ideas }\end{array}$ \\
\hline $\begin{array}{c}\text { Inner } \\
\text { motivationGG } 8 \\
\end{array}$ & $\begin{array}{c}\text { Attitude } \\
\text { Self-realization } \\
\end{array}$ & $\begin{array}{c}\text { Full of passion and confidence } \\
\text { Realize new value }\end{array}$ & $\begin{array}{l}\text { Full of faith and hope } \\
\text { Achievement needs }\end{array}$ \\
\hline competencyGG $_{9}$ & adaptability & Relatively strong & strong \\
\hline
\end{tabular}

Through the comparison and analysis of the key points found that key driving factors in the process of elite retired athletes' implicit human capital are that nine points in the table 5. According to the table 5 we can see that the key points in the two cases do not bring the same performance. In order to further explore and summarize the logic relation between the nine key points, we use the paradigm model to determine the key points at the heart then reveal the inner relationship and logic order between the main points and the others.

TABLE VI. PARADIGN MODEL OF MAIN POINT

\begin{tabular}{|c|c|c|c|}
\hline $\begin{array}{c}\text { Causal } \\
\text { conditions }\end{array}$ & Role transition $\mathrm{GG}_{1}$ & phenomenon & Self-perception $\mathrm{GG}_{4}$ \\
\hline context & $\begin{array}{l}\text { athletic characteristic } \mathrm{GG}_{5} \\
\text { Inner motivationGG }\end{array}$ & Intermediary conditions & $\begin{array}{l}\text { Social capital } \mathrm{GG}_{3} \\
\text { Opportunity } \mathrm{GG}_{6}\end{array}$ \\
\hline $\begin{array}{c}\text { Action / } \\
\text { interaction } \\
\text { strategy } \\
\end{array}$ & $\begin{array}{c}\text { Learn } \mathrm{GG}_{2} \\
\text { Innovation } \mathrm{GG}_{7}\end{array}$ & Result & competencyGG 9 \\
\hline
\end{tabular}


It follows that the key driving factors in the process of elite retired athletes' implicit human capital are selfperception, role transition, athletic characteristic, motivation, and social capital, opportunity, learning ability, innovation and competency.

\section{CONCLUSION AND ENLIGHTENMENT}

This study analysis two representative elite retired athletes' successful transition, including Deng Yaping and Huang Yanlan, based on grounded theory. Finally extract nine driving factors in the process of elite retired athletes' implicit human capital. Giving a review of the whole study, we obtain the following conclusion and enlightenment:

1) Self-awareness occupies the key status in the transition of the implicit human capital of elite retired athletes. Correct and objective self-perception reflects individual clear cognition of its own situation and the surrounding environments, guides the individual to self-adjusting and conscious control, identifies the employment environment, forms the reasonable expectation of employment, in order to better adapt the social environment.

2) Athletes lack of clear understanding and reasonable design of the future career before retiring, lead to the blind passive employment, cause the waste of excellent sports. So that athletes need reasonable self-image, bring out their best potentials and pinpoint their orientation and goal before retiring. On the other hand, enhance the guide and management of career design for athletes, turn passive employment to proactive planning employment.

\section{REFERENCES}

[1] Liu Yubin and Zhang Shan, "Research on the transformation of the implicit human capital of elite retired athletes,"Journal of Tianjin Institute of Physical Education, vol.6, pp. 468-471, 2013.

[2] Liu Yubin, "Research on the transformation of the implicit human capital of high-skilled talent based on the model of SECI,"Journal of Beijing Industry and Commerce University, vol.4, pp. 29-33, 2008.
[3] Liu Wen and Wang Jie, "The formation of employees' implicit human capital and its influence on job perfomance:based on private manufacturing enterprises," Journal of Shanxi University of Finance and Economics, vol.10, pp. 85-95, 2011.

[4] Zhao Shijun, Ge Yuhui, and Yu Lin, "Research on the relationshio between top management team's implicit human capital and team performance, "Enterprise Economy, vol.6, pp. 63-65, 2010.

[5] Strauss,A. and J. Corbin, "Grounded theory methodology-an overview in Norman K.D. and S.L. Yvonna,eds," Handbook of Qualitative Research, pp. 22-23, 1994.

[6] Wang Linan, "Research on the embedded risk of enterprise network organization based on the grounded stud:A case study of Cnro science and technology limited company," Tianjin University of Finance and Economics. Tianjin, pp. 3-5, 2012.

[7] Li Zhigang and Li Xingwang, "Research on rapid growth model and its influencing factors of Mengniu Corporation: the application of grounded theory research method," Management Science, pp. 2-7, 2006.

[8] Lijin, "Research on the driving factors of technological innovation in small and medium sized enterprises of science and technology," Nankai university, pp. 39-40, 2014.

[9] Getz D, "Event tourism: Definition, evolution, and research," Tourism Management,vol. 29, pp. 403-428, 2008

[10] Zhou Haangmei, "Research on career planning strategies of students in Higher Vocational Colleges," Journal of College of Nanjing Institute of Industry Technology, vol.9, pp. 163-165, 2004.

[11] Zou Qiuhong, "On the students' self cognition education in Higher Vocational Education,” Education Exploration, vol.6, pp. 10-12, 2005.

[12] Zheng Cailian, "A study on the relationship between students' self cognition and job hunting employment in Independent Colleges," Journal of China Youth University for Political Science, vol.2, pp. 1821, 2007.

[13] Lin Nan, "Social capital: Theory of social structure and action," Shanghai People's Publishing House. Shanghai, 2005.

[14] Wang Jin, "The implementation of vocational skills training for retired athletes during the transition period -- Based on the perspective of CBE theory," Jorunal of Physical Education Institute of Shanxi Teachers University, vol. 25, no.6, pp.31-33, 2010. 